\title{
Growth Response and Crop Production (Brassica Juncea L.) Against Watering Time Interval at Various Hydroponics Media
}

\author{
Muhammad Zailani ${ }^{1}$, Retno Astuti Kuswardani ${ }^{1}$, Ellen L. Panggabean ${ }^{1}$ \\ ${ }^{1}$ Faculty of Agriculture, University of Medan Area, Indonesia \\ zailaniumafp@gmail.com
}

\begin{abstract}
This study aims to determine the Response Growth and Production of Crops (Brassica juncea L.) Against Watering Time Interval In Various Hydroponics Media. The research was conducted at the experimental gardens of Faculty of Agriculture, Faculty of Agriculture, University of Medan Area, located on No. Pond Street. 1 Medan Estate. This research was conducted from October 2013 until December 2013. The design used was RAL Factorial, with 2 replications, 10 combinations. The first factor of the hydroponic planting medium is: M1: Frying Roots, M2: Coconut Coir Powder, M3: Fryer Seal, M4: Rokwool, and M5: Sawdust, the second factor is the time interval: I1: 3 hours a day I2: 5 hours a day, starting from 08:00 a.m to 06:00 p.m. The result of this research indicates that the treatment of watering liquid fertilizer with different time interval does not show a real effect on the growth of mustard plants, Media treatment used on hydroponic systems have an influence very evident on the parameters of plant height, leaf number, leaf area, production weight and significant effect on leaf level parameters, influential planting medium and have the best number is M3 (fuel husk). Interaction interval of watering time on various hydroponic media did not have a significant effect on observed parameters, namely: plant height, leaf number, wet weight, and weight of production, while the leaf color parameter had significant effect on leaf width.
\end{abstract}

Keywords : hydroponics; sawi (brassica juncea l.); planting media; watering time

\section{Introduction}

Demand for vegetable commodities in Indonesia continues to increase, along with increasing population and per capita consumption. Besides that, some people also want more quality horticulture products. The increasing number of vegetable commodities from abroad indicates that market demand has not been able to be met by domestic production. If this condition continues, Indonesia will be highly dependent on imported horticulture products. Vegetable consumption in Indonesia in 2009 is $45.80 \mathrm{~kg} /$ capita / year, this is still lower than the minimum requirement recommended by FAO, which is $65 \mathrm{~kg} /$ capita / year. Because the national production of vegetables is still lower than consumption which is equal to $45.80 \mathrm{~kg} /$ capita / year. (Ministry of Agriculture, 2010), thus there is still a very wide open increase in production to be able to meet national vegetable consumption levels. One of them is mustard greens. Mustard plants are rich in sources of vitamin A, so they are effective in trying to overcome the problem of vitamin A deficiency or myopic disease until now a problem among children under five (Margiyanto, 2007)

Good mustard growth can not be separated from the role of the planting media, because of the nutritional intake needed by mustard plants. Planting media is a decisive factor for the development of growth. Fertile soil must contain macro and micro nutrients. the mineralization process in the soil will become nutrients which are ready to be absorbed by plants and other life in the soil. Minerals also maintain the stability of the shape and structure of the soil so that its component composition is not easily changed by the effects of changes 
and movements in the soil, so that it can support plants and provide space for life for the roots of plants and other living things in the soil. To get good fertility, soil treatment is also carried out. In general, sprinkling aims to improve soil structure and air circulation as well as providing basic fertilizers to improve the physical and chemical soil which will increase the fertility of the land we will use.

Agricultural land is increasingly narrow due to the shifting of the function of agricultural land into industrial areas, so that hydroponic cultivation is considered appropriate to utilize available land because this cultivation system does not require soil media. The hydroponic system uses a variety of planting media other than soil, among others, with media such as fuel husk, husk, sand, zeolite, rockwoll, peat (peat moss) and coconut husk powder (Prihmantoro and Indriani, 2010).

Hydroponic cultivation can provide more benefits than traditional farming systems. The advantages that can be obtained include: harvested when really cooked, can be done close to the market or consumers, does not depend on the season and can be adjusted to the high market demand, guaranteed optimal growth climate because the environment is controlled, there is no problem with the land because it does not use soil media, safer because of handling biological pests and diseases, high quality results will be accepted by consumers at high prices so as to provide high profits as well (CropKing Inc., 2003). Suhardiyanto (2002) states that the cultivation of plants with a hydroponic system has advantages over planting in soil media. Some of the advantages of hydroponic systems include: cleanliness is more easily maintained, does not need soil treatment, efficient use of water and fertilizers, does not depend on the season, can be obtained higher product quality, higher productivity can be done with organic systems, and can be cultivated on narrow land. Some types of leaf vegetables that can be cultivated hydroponically include spinach, caisim, kale, lettuce and others (Sutiyoso, 2003).

\section{Methodology}

The materials used in this study were mustard seeds, biosubur liquid fertilizer, ferns, sawdust, roasted husks, coconut fiber, rockwool. The tools used in this research are plastic plastics, paralon pipes, paranet, zinc fiber, mineral water glass, rollers, handsprayers, knives, tweezers, $\mathrm{pH}$ meters, thermometers, and stationery.

The research method used in this study is experimental which directly conducts experiments in the field with the application of planting media, which aims to determine the effect of interaction between media with watering time intervals and determine the growth rate and production of mustard plants. The research method used is Factorial Completely Randomized Design, namely: (1) Planting media (M) consists of 5 levels, namely: M1 = Planting media for ferns, M2 = Media for coconut husk planting, M3 = Media for burning husk, M4 = Sawdust planting media, M5 = Rockwool planting media. (2) Watering time interval consists of 2 levels, namely: $\mathrm{I} 1=3$ hours, $\mathrm{I} 2=5$ hours. In this experiment there were 10 combinations for each experiment repeated 3 times.

The data analysis method used is variance analysis:

Information :

$$
\text { Yijk }=\mu+\rho i+\alpha j+\beta k+(\alpha \beta) j k+\varepsilon i j k
$$

Yijk $=$ Observation on the second block with treatment of watering interval at level $\mathrm{j}$ and various types of media at level $\mathrm{k}$ 
$\mu \quad=$ Middle value

$\mathrm{i} \quad$ i-block effect

$\alpha \mathrm{j}=$ the effect of treatment on the watering interval at the jth level

$\beta \mathrm{k}=$ the effect of the treatment of several types of media on the karak

$(\alpha \beta) \mathrm{jk}=$ effect of interaction between time interval at level $\mathrm{j}$ and planting media at level $\mathrm{k}$

Eijk $=$ the effect of error on the $\mathrm{i}$ block which gets the treatment time interval at the $\mathrm{j}$ level and the planting media at the kth level

If the results of variance show significant differences, then proceed with the Duncan Multiple Range test (DMRT) test at the level of 5\% (Sastrosupadi, 2002).

\section{Plant Height}

\section{Result and Discussion}

Observation data of mustard plant height at the age of 1-5 MST showed no significant effect by administering a watering time interval treatment, the treatment of various planting media showed a very real effect, while the combination treatment showed results that were not real. The average observation results of mustard plants are presented in Tables 1, 2 and 3 .

Table 1. Average Watering Time Interval (I) at Mustard Plant Height $(\mathrm{cm})$ Age 1-5 MST

\begin{tabular}{llllll}
\hline \multirow{2}{*}{ Treatment } & \multicolumn{4}{c}{ Plant Height (cm) } \\
\cline { 2 - 6 } & Week 1 & Week 2 & Week 3 & Week 4 & Week 5 \\
\hline I1 & 9,57 tn & 13,61 tn & 17,03 tn & 21,11 tn & 23,16 tn \\
I2 & 9,09 tn & 13,75 tn & $16,91 \mathrm{tn}$ & $21,26 \mathrm{tn}$ & $22,76 \mathrm{tn}$ \\
\hline
\end{tabular}

Note : tn : not real

Table 2. Average media (M) At mustard plant height (cm) aged 1-5 MST

\begin{tabular}{llllll}
\hline \multirow{2}{*}{ Treatment } & \multicolumn{5}{c}{ Plant Height (cm) } \\
\cline { 2 - 6 } & Week 1 & Week 2 & Week 3 & Week 4 & Week 5 \\
\hline M1 & $9,82 \mathrm{tn}$ & $14,99 \mathrm{aA}$ & $19,20 \mathrm{aA}$ & $22,45 \mathrm{cC}$ & $23,55 \mathrm{cC}$ \\
M2 & $9,37 \mathrm{tn}$ & $15,30 \mathrm{aA}$ & $19,25 \mathrm{aA}$ & $25,40 \mathrm{bB}$ & $27,83 \mathrm{bB}$ \\
M3 & $10,16 \mathrm{tn}$ & $15,53 \mathrm{aA}$ & $20,25 \mathrm{aA}$ & $28,90 \mathrm{aA}$ & $32,86 \mathrm{aA}$ \\
M4 & $8,99 \mathrm{tn}$ & $9,87 \mathrm{cC}$ & $11,07 \mathrm{cC}$ & $12,75 \mathrm{eE}$ & $13,50 \mathrm{eE}$ \\
M5 & $8,21 \mathrm{tn}$ & $12,70 \mathrm{bB}$ & $15,07 \mathrm{bB}$ & $16,43 \mathrm{dD}$ & $16,68 \mathrm{dD}$ \\
\hline
\end{tabular}

Note: Numbers followed by the same letters in the same column are not significantly different at the level of $\alpha=$ 0.05 (small letters) and at the level of $\alpha=0.01$ (uppercase) based on the Duncan distance test.

Table 3. Average Interaction of Watering Time Intervals in Various Media (M X I) On Height of Mustard Plants (cm) Age 1-5.

\begin{tabular}{clllll}
\hline \multirow{2}{*}{ Treatment } & \multicolumn{5}{c}{ Plant Height (cm) } \\
\cline { 2 - 6 } & Week 1 & Week 2 & Week 3 & Week 4 & Week 5 \\
\hline M1 I1 & 10,25 tn & 15,50 tn & 19,65 tn & 22,85 tn & 25,10 tn \\
M2 I1 & 9,93 tn & 15,25 tn & $18,80 \mathrm{tn}$ & $24,55 \mathrm{tn}$ & $27,40 \mathrm{tn}$
\end{tabular}




\begin{tabular}{llllll} 
M3 I1 & $10,45 \mathrm{tn}$ & $14,51 \mathrm{tn}$ & $19,45 \mathrm{tn}$ & $28,45 \mathrm{tn}$ & $33,15 \mathrm{tn}$ \\
M4 I1 & $8,88 \mathrm{tn}$ & $10,39 \mathrm{tn}$ & $11,45 \mathrm{tn}$ & $12,65 \mathrm{tn}$ & $12,45 \mathrm{tn}$ \\
M5 I1 & $8,33 \mathrm{tn}$ & $12,40 \mathrm{tn}$ & $15,80 \mathrm{tn}$ & $17,05 \mathrm{tn}$ & $17,70 \mathrm{tn}$ \\
\hline M1 I2 & $9,39 \mathrm{tn}$ & $14,48 \mathrm{tn}$ & $18,75 \mathrm{tn}$ & $22,05 \mathrm{tn}$ & $23,55 \mathrm{tn}$ \\
M2 I2 & $8,80 \mathrm{tn}$ & $15,35 \mathrm{tn}$ & $19,70 \mathrm{tn}$ & $26,25 \mathrm{tn}$ & $28,25 \mathrm{tn}$ \\
M3 I2 & $9,86 \mathrm{tn}$ & $16,55 \mathrm{tn}$ & $21,05 \mathrm{tn}$ & $29,35 \mathrm{tn}$ & $32,20 \mathrm{tn}$ \\
M4 I2 & $9,11 \mathrm{tn}$ & $9,35 \mathrm{tn}$ & $10,70 \mathrm{tn}$ & $12,85 \mathrm{tn}$ & $14,55 \mathrm{tn}$ \\
M5 I2 & $8,26 \mathrm{tn}$ & $13,00 \mathrm{tn}$ & $14,35 \mathrm{tn}$ & $15,80 \mathrm{tn}$ & $15,65 \mathrm{tn}$ \\
\hline
\end{tabular}

Based on Table 1 above shows that the watering treatment has no significant effect on plant height at the age of 1-5 MST, while the media treatment did not significantly affect the age of 1 MST and had a very significant effect at the age of 2-5 MST, the best average for treatment The media is shown in Table 2 and in the following graph:

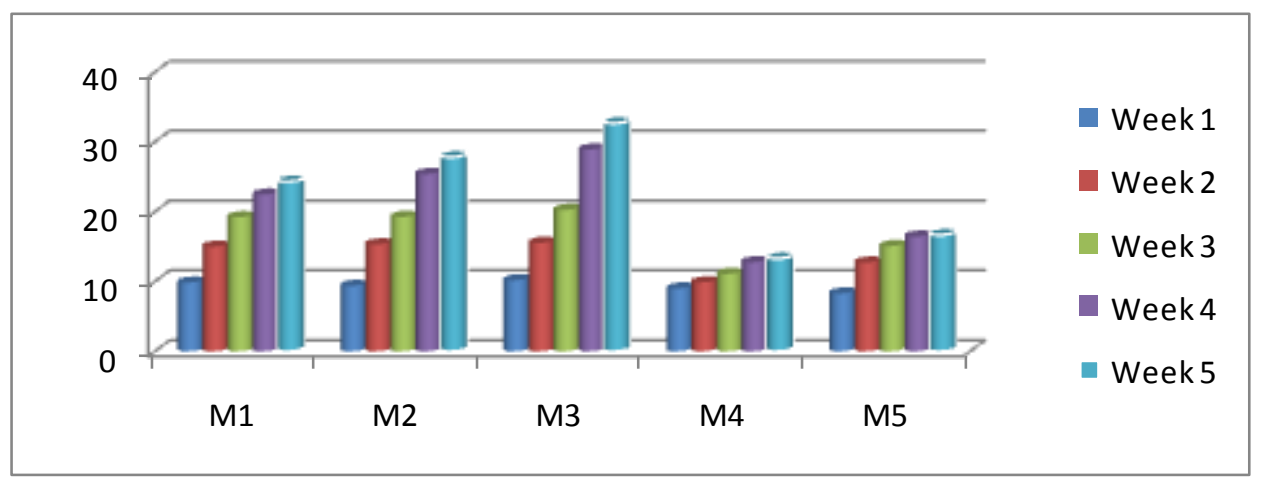

Figure 2. High Media Average Graph of Plants 1-5 MST

But the treatment of watering interactions on various media does not show significant differences in plant growth. Of the several treatments M3 I1 has the best average match with M3 I2 with an average plant height of $33.15 \mathrm{~cm}$ and the lowest average plant height of 12.45 $\mathrm{cm}$ found in treatment M4 I1. The watering treatment on different planting media showed no significant effect at the age of 1-5 MST seen in Table 3.

This is because the growth of plants or plants is influenced by several factors, namely nutrient ions or mineral salts absorbed by the leaves and photosynthesis. Where absorption and photosynthesis will not run optimally if the leaf's fresh period is lower than the dry period of the leaves, the dry period itself becomes a more legitimate estimate to determine the clues that indicate the absence of growth, while the fresh period determines the growth of a plant because the fresh leaves occur photosynthesis and greater salt deposition. Similarly, plants planted by hydroponics always receive adequate nutritional intake so that the growth of hydroponic plants is more stable than horticultural plants (Salisbury et al. 1992). 


\section{Number of Leaves}

Observation data on the number of mustard plant leaves at the age of 1-5 MST showed no significant effect by administering watering time intervals, the treatment of various planting media showed a very real effect, while the combination treatment showed results that were not real. The average observation results of the number of mustard leaves are presented in Tables 4, 5 and 6.

Table 4. Average Watering Time Intervals (I) Number of Leaves (Strands) of Mustard Plants Age 1-5 MST

\begin{tabular}{llllll}
\hline \multirow{2}{*}{ Treatment } & \multicolumn{5}{c}{ Number of Leaves (Strands) } \\
\cline { 2 - 6 } & Week 1 & Week 2 & Week 3 & Week 4 & Week 5 \\
\hline I1 & 2,7 tn & 3,5 tn & 4,0 tn & 5,3 tn & 6,0 tn \\
\hline I2 & 2,9 tn & 3,4 tn & 4,2 tn & 5,6 tn & 6,2 tn \\
\hline
\end{tabular}

Note: tn : not real

Table 5. Media Average (M) in Number of Leaves (Strands) of Sawiumur Plants 1-5MST

\begin{tabular}{llllll}
\hline & \multicolumn{5}{c}{ Number of Leaves (Strands) } \\
\cline { 2 - 6 } Treatment & Week 1 & Week 2 & Week 3 & Week 4 & Week 5 \\
\hline M1 & $3,1 \mathrm{a}$ & $3,9 \mathrm{aA}$ & $4,7 \mathrm{aA}$ & $5,9 \mathrm{bB}$ & $6,1 \mathrm{cB}$ \\
M2 & $2,8 \mathrm{a}$ & $3,6 \mathrm{aA}$ & $4,4 \mathrm{aA}$ & $6,0 \mathrm{bB}$ & $7,1 \mathrm{bB}$ \\
M3 & $3,1 \mathrm{a}$ & $3,9 \mathrm{aA}$ & $4,7 \mathrm{aA}$ & $7,2 \mathrm{aA}$ & $8,7 \mathrm{aA}$ \\
M4 & $2,3 \mathrm{~b}$ & $2,4 \mathrm{bB}$ & $2,7 \mathrm{cC}$ & $3,8 \mathrm{cC}$ & $3,9 \mathrm{dC}$ \\
M5 & $2,7 \mathrm{a}$ & $3,5 \mathrm{aA}$ & $3,6 \mathrm{bB}$ & $4,5 \mathrm{cC}$ & $4,6 \mathrm{dC}$ \\
\hline
\end{tabular}

Description: Numbers followed by the same letters in the same column are not significantly different at the level of $\alpha=0.05$ (lowercase letters) and at the level of $\alpha=0.01$ (uppercase) based on Duncan's distance test

Table 6. Average Interaction of Watering Intervals at Various Media (M X I) Number of Leaves (Strands) of Mustard Plants Age 1-5 MST.

\begin{tabular}{llllll}
\hline & \multicolumn{5}{c}{ Number of Leaves (Strands) } \\
\cline { 2 - 6 } Treatment & Week 1 & Week 2 & Week 3 & Week 4 & Week 5 \\
\hline M1 I1 & 3,0 tn & 3,9 tn & 4,7 tn & 5,8 tn & 5,8 tn \\
M2 I1 & 2,6 tn & 3,8 tn & 4,3 tn & 5,7 tn & 6,9 tn \\
M3 I1 & 2,9 tn & 3,8 tn & 4,2 tn & 7,0 tn & 8,7 tn \\
M4 I1 & 2,2 tn & 2,6 tn & 2,7 tn & 3,7 tn & 3,7 tn \\
M5 I1 & 2,7 tn & 3,4 tn & 3,8 tn & 4,4 tn & 4,8 tn \\
\hline M1 I2 & 3,1 tn & 3,9 tn & 4,7 tn & 6,0 tn & 6,4 tn \\
M2 I2 & 3,0 tn & 3,4 tn & 4,5 tn & 6,3 tn & 7,4 tn
\end{tabular}




\begin{tabular}{llllll} 
M3 I2 & 3,3 tn & 4,0 tn & 5,3 tn & 7,4 tn & 8,7 tn \\
M4 I2 & 2,4 tn & 2,2 tn & 2,8 tn & 3,9 tn & 4,2 tn \\
M5 I2 & 2,7 tn & 3,5 tn & 3,5 tn & 4,5 tn & 4,5 tn \\
\hline
\end{tabular}

Note: tn : not real

From Table 4 above, it can be seen that the watering time interval did not significantly affect the number of mustard plant leaves at the age of 1-5 MST, while the mean media had a significant effect on the age of 1 MST and at the age of 2-5 MST the effect was very significant on media treatment planting on the number of leaves is shown in Table 5 and the following graph:

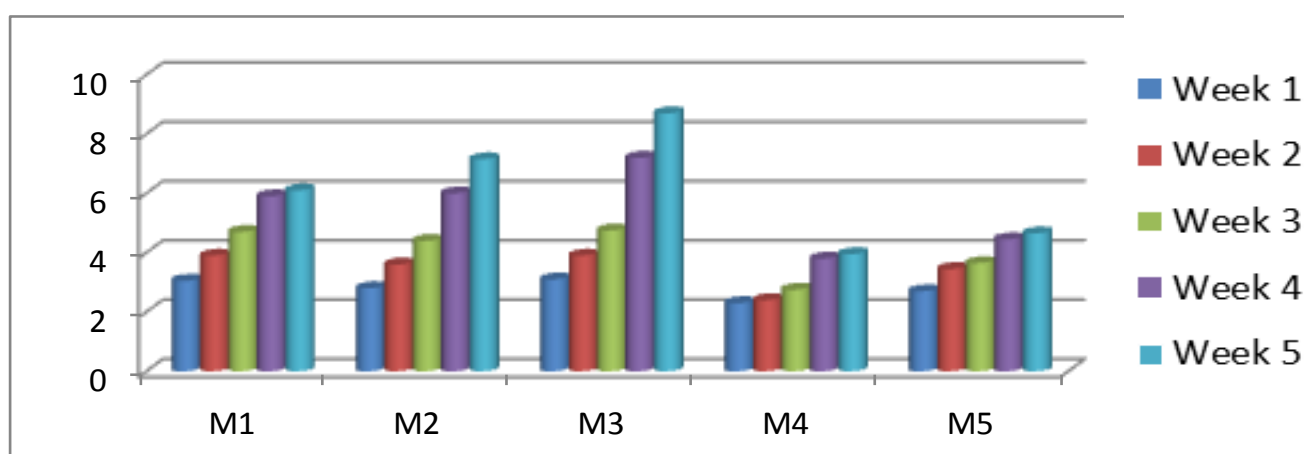

Figure 3. Media Average Graph Number of Leaves 1-5 MST

And the average interaction of the number of mustard plants leaves no significant effect at the age of 1-5 MST can be seen in Table 6, from the average interaction of the number of leaves treated M3 I1 and M3 I2 is the best average of all treatments, namely 8.7 strands.

\section{Leaf Color}

Observation data of leaf color of mustard plants at the age of 1-5 MST showed no significant effect by administering a watering time interval treatment, the treatment of various planting media showed a very real effect, while the combination treatment showed results that were not real. The average observations of leaf color of mustard plants are presented in Tables 7,8 and 9.

Table 7. Average Watering Time Interval (I) in Leaf Colors of Mustard Plants of 1-5 MST Age

\begin{tabular}{llllll}
\hline \multirow{2}{*}{ Treatment } & \multicolumn{5}{c}{ Leaf Color } \\
\cline { 2 - 6 } & Week 1 & Week 2 & Week 3 & Week 4 & Week 5 \\
\hline I1 & 3,50 tn & 3,90 tn & 3,82 tn & 4,22 tn & 4,52 tn \\
\cline { 2 - 6 } I2 & 3,66 tn & 4,02 tn & 4,08 tn & 4,32 tn & 4,70 tn \\
\hline
\end{tabular}


Table 8. Media Average (M) in Leaf Colors of Mustard Plants of 1-5 MST Age

\begin{tabular}{llllll}
\hline \multirow{2}{*}{ Treatment Leaf Color } \\
\cline { 2 - 6 } & Week 1 & Week 2 & Week 3 & Week 4 & Week 5 \\
\hline M1 & $3,9 \mathrm{a}$ & $4,6 \mathrm{aA}$ & $4,2 \mathrm{a}$ & $4,5 \mathrm{a}$ & $5,0 \mathrm{a}$ \\
M2 & $3,6 \mathrm{a}$ & $3,8 \mathrm{bB}$ & $4,1 \mathrm{a}$ & $4,1 \mathrm{a}$ & $4,7 \mathrm{a}$ \\
M3 & $3,7 \mathrm{a}$ & $4,1 \mathrm{aA}$ & $4,2 \mathrm{a}$ & $4,2 \mathrm{a}$ & $4,8 \mathrm{a}$ \\
M4 & $2,9 \mathrm{~b}$ & $3,1 \mathrm{cC}$ & $3,2 \mathrm{~b}$ & $3,8 \mathrm{a}$ & $3,9 \mathrm{~b}$ \\
M5 & $3,7 \mathrm{a}$ & $4,1 \mathrm{bA}$ & $3,9 \mathrm{a}$ & $4,6 \mathrm{a}$ & $4,5 \mathrm{a}$ \\
\hline
\end{tabular}

Description: Numbers followed by the same letters in the same column are not significantly different at the level of $\alpha=0.05$ (lowercase) and at the level of $\alpha=0.01$ (uppercase) based on the Duncan distance test.

Table 9. Mean Interaction of Watering Time Intervals in Various Media (Mxi) Leaf Color (Strands) of Mustard Plants Age 1-5 MST

\begin{tabular}{llllll}
\hline \multirow{2}{*}{ Treatment } & \multicolumn{5}{c}{ Leaf Color } \\
\cline { 2 - 6 } & Week 1 & Week 2 & Week 3 & Week 4 & Week 5 \\
\hline M1 & 3,9 tn & $4,5 \mathrm{~b}$ & $4,2 \mathrm{tn}$ & $4,4 \mathrm{tn}$ & $5,0 \mathrm{tn}$ \\
M2 & $3,7 \mathrm{tn}$ & $3,9 \mathrm{c}$ & $4,2 \mathrm{tn}$ & $4,0 \mathrm{tn}$ & $4,8 \mathrm{tn}$ \\
M3 & $3,4 \mathrm{tn}$ & $3,7 \mathrm{~d}$ & $4,1 \mathrm{tn}$ & $4,1 \mathrm{tn}$ & $4,9 \mathrm{tn}$ \\
M4 & $2,8 \mathrm{tn}$ & $3,3 \mathrm{e}$ & $2,8 \mathrm{tn}$ & $3,7 \mathrm{tn}$ & $3,4 \mathrm{tn}$ \\
M5 & $3,7 \mathrm{tn}$ & $4,1 \mathrm{c}$ & $3,8 \mathrm{tn}$ & $4,9 \mathrm{tn}$ & $4,5 \mathrm{tn}$ \\
\hline M1 & $3,9 \mathrm{tn}$ & $4,7 \mathrm{a}$ & $4,3 \mathrm{tn}$ & $4,6 \mathrm{tn}$ & $5,0 \mathrm{tn}$ \\
M2 & $3,5 \mathrm{tn}$ & $3,7 \mathrm{~d}$ & $4,0 \mathrm{tn}$ & $4,3 \mathrm{tn}$ & $4,7 \mathrm{tn}$ \\
M3 & $4,1 \mathrm{tn}$ & $4,6 \mathrm{a}$ & $4,4 \mathrm{tn}$ & $4,4 \mathrm{tn}$ & $4,7 \mathrm{tn}$ \\
M4 & $3,1 \mathrm{tn}$ & $3,0 \mathrm{f}$ & $3,6 \mathrm{tn}$ & $3,9 \mathrm{tn}$ & $4,5 \mathrm{tn}$ \\
M5 & $3,7 \mathrm{tn}$ & $4,1 \mathrm{c}$ & $4,1 \mathrm{tn}$ & $4,4 \mathrm{tn}$ & $4,6 \mathrm{tn}$ \\
\hline
\end{tabular}

Description: Numbers followed by the same letters in the same column are not significantly different at the level of $\alpha=0.05$ (lowercase letters) based on the Duncan distance test.

Based on observational data in Table 7, the watering treatment did not significantly affect each treatment, while the treatment of various media had a significant effect on 1 MST and at 2 MST the effect was very real, but in 3-5 MTS only had a significant effect. From the observation data, all leaves have a relatively good color, according to the leaf color chart of treatment, namely M1 M2, M3, and M5 shows the average number 4. Except for treatment M4 does not show a mean number below 4, which is 3.9 as shown in Table 8 above and the best treatment can be seen in the following graphic: 


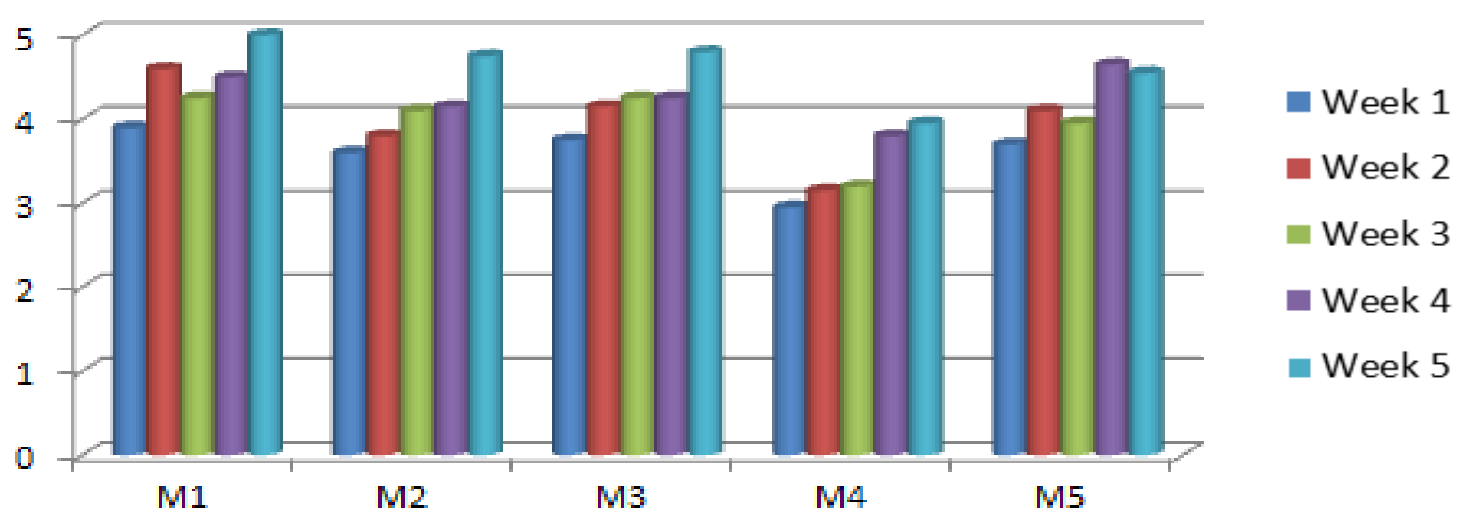

Figure 4: Media Average Graph of leaf color 1-5 MST

The interaction of watering time intervals on various media did not significantly affect leaf color at age 1 MST but had a significant effect on 2 MST and in 3-5MST no significant effect, can be seen in Table 9.

\section{Leaf Area (cm2)}

Observation data of leaf area of mustard plants at the age of 1-5 MST showed no significant effect by administering the watering time interval treatment, the treatment of various planting media showed a very real effect, while the combination treatment showed results that were not real. The average observation results of leaf area of mustard plants are presented in Tables 10, 11 and 12.

Table 10. Average Watering Time Interval (I) on Leaf Area (Cm2) Mustard Plants Age 1-5 MST

\begin{tabular}{clllll}
\hline \multirow{2}{*}{ Treatment } & \multicolumn{5}{c}{ Leaf Area $\left(\mathrm{cm}^{2}\right)$} \\
\cline { 2 - 6 } & Week 1 & Week 2 & Week 3 & Week 4 & Week 5 \\
\hline $\mathrm{I} 1$ & $10,11 \mathrm{tn}$ & $19,01 \mathrm{tn}$ & $35,43 \mathrm{tn}$ & $46,02 \mathrm{tn}$ & $58,73 \mathrm{tn}$ \\
\hline $\mathrm{I} 2$ & $9,60 \mathrm{tn}$ & $18,80 \mathrm{tn}$ & $31,60 \mathrm{tn}$ & $46,50 \mathrm{tn}$ & $59,80 \mathrm{tn}$ \\
\hline
\end{tabular}

Note: tn : not real

Table 11. Mean Media (M) in Leaf Area (Cm2) Mustard Plants Age 1-5 MST.

\begin{tabular}{clllll}
\hline \multirow{2}{*}{ Treatment } & \multicolumn{5}{c}{ Leaf Area $\left(\mathrm{cm}^{2}\right)$} \\
\cline { 2 - 6 } & Week 1 & Week 2 & Week 3 & Week 4 & Week 5 \\
\hline M1 & $12,00 \mathrm{tn}$ & $22,25 \mathrm{aA}$ & $39,75 \mathrm{aA}$ & $47,25 \mathrm{bA}$ & $56,75 \mathrm{bA}$ \\
M2 & $10,91 \mathrm{tn}$ & $22,11 \mathrm{aA}$ & $43,06 \mathrm{aA}$ & $58,25 \mathrm{aA}$ & $82,16 \mathrm{aA}$ \\
M3 & $11,30 \mathrm{tn}$ & $23,06 \mathrm{aA}$ & $47,30 \mathrm{aA}$ & $78,07 \mathrm{aA}$ & $102,73 \mathrm{aA}$ \\
M4 & $7,30 \mathrm{tn}$ & $9,32 \mathrm{bB}$ & $12,00 \mathrm{cC}$ & $16,37 \mathrm{cB}$ & $19,51 \mathrm{cB}$ \\
M5 & $7,77 \mathrm{tn}$ & $17,76 \mathrm{aA}$ & $25,46 \mathrm{bB}$ & $31,35 \mathrm{cB}$ & $35,15 \mathrm{bB}$ \\
\hline
\end{tabular}

Description: Numbers followed by the same letters in the same column are not significantly different at the level of $\alpha=0.05$ (lowercase) and at the level of $\alpha=0.01$ (uppercase) based on the Duncan distance test. 
Table 12. Average Interaction of Watering Time Intervals in Various Media (Mxi) on Leaf Area (Cm2) Mustard Plants Age 1-5 MST.

\begin{tabular}{llllll}
\hline \multirow{2}{*}{ Treatment } & \multicolumn{5}{c}{ Leaf Area $\left(\mathrm{cm}^{2}\right)$} \\
\cline { 2 - 6 } & Week 1 & Week 2 & Week 3 & Week 4 & Week 5 \\
\hline M1 I1 & $12,5 \mathrm{aA}$ & $22,5 \mathrm{aA}$ & $42,50 \mathrm{bB}$ & $50,50 \mathrm{bB}$ & $60,50 \mathrm{cB}$ \\
M2 I1 & $11,32 \mathrm{bB}$ & $22,71 \mathrm{aA}$ & $42,12 \mathrm{bB}$ & $55,00 \mathrm{bB}$ & $74,33 \mathrm{cB}$ \\
M3 I1 & $9,09 \mathrm{cC}$ & $22,12 \mathrm{aA}$ & $54,10 \mathrm{aA}$ & $83,65 \mathrm{aA}$ & $113,45 \mathrm{aA}$ \\
M4 I1 & $8,59 \mathrm{dD}$ & $9,15 \mathrm{cC}$ & $12,50 \mathrm{eD}$ & $14,25 \mathrm{eE}$ & $15,03 \mathrm{fD}$ \\
M5 I1 & $9,05 \mathrm{dD}$ & $18,53 \mathrm{bB}$ & $25,91 \mathrm{dC}$ & $26,70 \mathrm{dD}$ & $30,31 \mathrm{eC}$ \\
\hline M1 I2 & $11,50 \mathrm{bB}$ & $22,00 \mathrm{aA}$ & $37,00 \mathrm{cB}$ & $44,00 \mathrm{dC}$ & $53,00 \mathrm{dC}$ \\
M2 I2 & $10,50 \mathrm{cC}$ & $21,50 \mathrm{aA}$ & $44,00 \mathrm{bB}$ & $61,50 \mathrm{cB}$ & $90,00 \mathrm{bA}$ \\
M3 I2 & $13,50 \mathrm{aA}$ & $24,00 \mathrm{aA}$ & $40,50 \mathrm{cB}$ & $72,50 \mathrm{aA}$ & $92,00 \mathrm{bA}$ \\
M4 I2 & $6,00 \mathrm{eE}$ & $9,50 \mathrm{cC}$ & $11,50 \mathrm{eD}$ & $18,50 \mathrm{dC}$ & $24,00 \mathrm{eD}$ \\
M5 I2 & $6,50 \mathrm{eE}$ & $17,00 \mathrm{bB}$ & $25,00 \mathrm{dC}$ & $36,00 \mathrm{cC}$ & $40,00 \mathrm{dC}$ \\
\hline
\end{tabular}

Description: Numbers followed by the same letters in the same column are not significantly different at the level of $\alpha=0.05$ (lowercase letters) and at the level of $\alpha=0.01$ (uppercase) based on Duncan's distance test.

The results of observations of leaf area on the average watering time interval were not significantly seen in Table 10, whereas the observation of media averages did not significantly affect age 1 . MST and very different at age 2-5 MST, can be broken down in Table 11 and the best media can be seen in Figure 5.

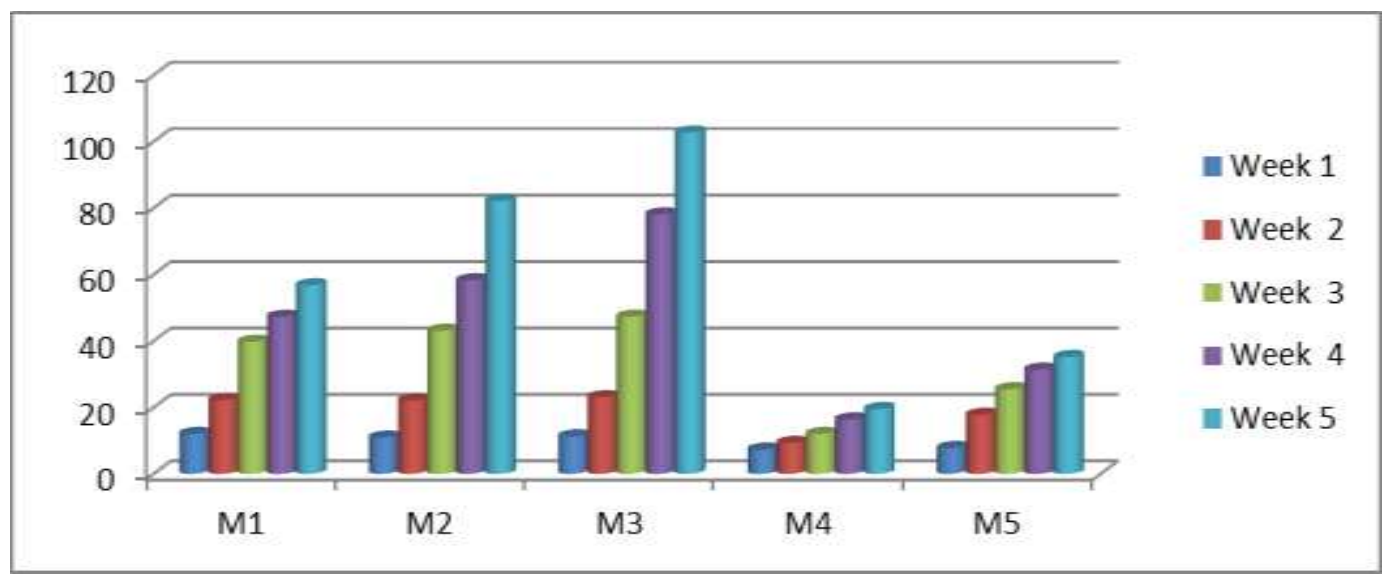

Figure 5. Average Graph of Leaves for Ages 1-5 MST

While the average interaction of watering time intervals on various media has a very significant effect on observations from the age of 1-5 MST. Measurement of leaf area aged 15 MST on the average leaf area of plants which showed the highest number seen in the treatment of M3 I1, namely the average leaf area reached $113.45 \mathrm{~cm} 2$, followed by treatment M3 I2 and M2 I2: $92 \mathrm{~cm} 2,90 \mathrm{~cm} 2$ and average the average leaf area of plants which shows the lowest number can be seen in the treatment of M4 I1 and M4 I2, namely the average leaf area reaches $15.025 \mathrm{~cm} 2$ and $24 \mathrm{~cm} 2$, seen in Table 12 and the best average can be seen in the following graph: 


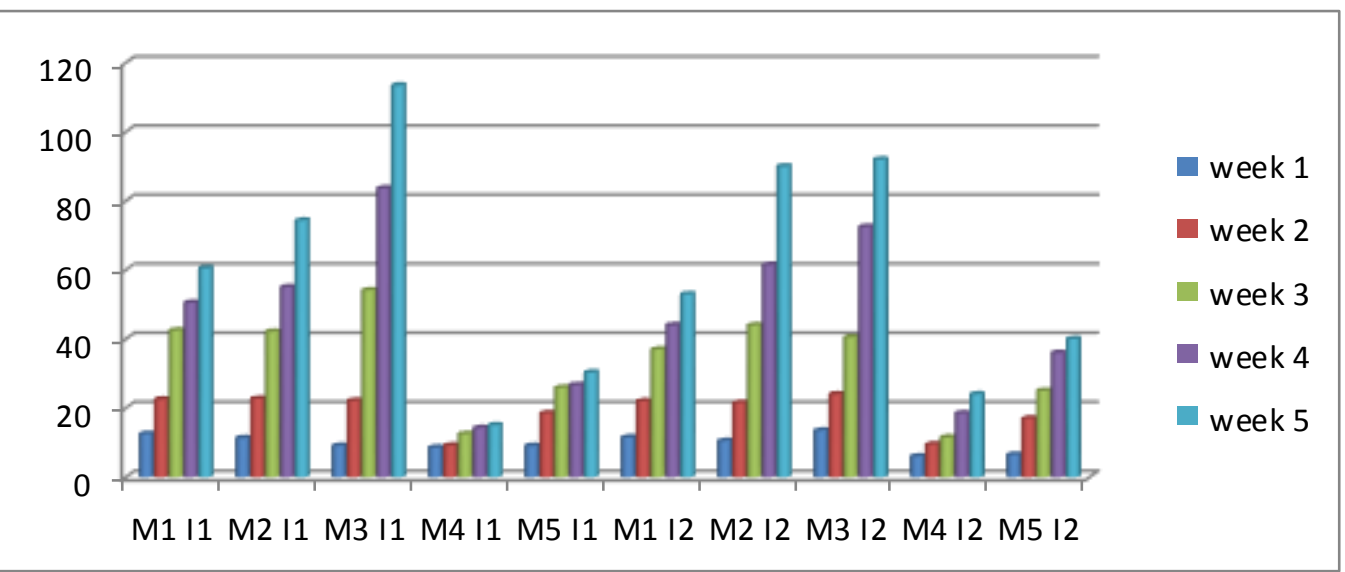

Figure 6: Average Leaf Width Interaction Chart

This is in line with the research of Topan (2009) stating that mustard plants planted using hydroponic husk charcoal showed the best results because they showed an influence on the parameters of leaf number, leaf width, plant height, production weight and root weight. The statement is also supported by the research of Silvina and Syafrinal (2008), stating that the use of husk charcoal has a good production effect on Japanese cucumbers compared to other media, namely sand media. This is because the husk charcoal media has the advantage that the porosity is better, the hollow is much so that aerase and drainage are good. Thus the roots will move easily and absorb nutrients better.

\section{Harvest Wet Weight}

The average wet weight of mustard plants with watering time intervals on various hydroponic media at the age of 5 MST can be seen in the following Table.

Table 13. Average Data of Watering Time Interval (I) on Wet Weight of Mustard Crop Harvest Age 5 MST.

\begin{tabular}{ll}
\hline Treatment & Wet weight harvest \\
\hline I1 & $238,04 \mathrm{tn}$ \\
I2 & $151,67 \mathrm{tn}$ \\
\hline
\end{tabular}

Note : tn : not real

Table 14. Media Average Data (M) on Harvest Wet Weight (G) Sawiumur Plant 5 MST

\begin{tabular}{ll}
\hline Treatment & Wet weight harvest \\
\hline M1 & $202,35 \mathrm{tn}$ \\
M2 & $270,37 \mathrm{tn}$ \\
M3 & $352,92 \mathrm{tn}$ \\
M4 & $70,85 \mathrm{tn}$ \\
M5 & $77,77 \mathrm{tn}$ \\
\hline \multicolumn{2}{l}{ Note : tn : not real }
\end{tabular}

Observation of harvest wet weight at watering time intervals had no significant effect on each treatment seen in Table 13. Whereas observations of harvest wet weight on media also did not significantly affect each treatment. But M3, which is husk charcoal media where husk charcoal with medium porosity is high enough that can hold water and nutrients, helps the growth of mustard plants to be better, seen in Table 14. And based on the data in Table 15 
interaction treatment watering time intervals in various media states no significant effect on each of the other treatments

Table 15. Mean Data on Interaction of Watering Intervals at Various Media (M X I) Wet Harvest Weight (G) Sawiumur Plant 5 MST

\begin{tabular}{ll}
\hline Treatment & \multicolumn{1}{c}{ Wet weight harvest } \\
\hline M1 I1 & $234,00 \mathrm{tn}$ \\
M2 I1 & $343,00 \mathrm{tn}$ \\
M3 I1 & $442,50 \mathrm{tn}$ \\
M4 I1 & $70,25 \mathrm{tn}$ \\
M5 I1 & $100,45 \mathrm{tn}$ \\
M1 I2 & $170,70 \mathrm{tn}$ \\
M2 I2 & $197,75 \mathrm{tn}$ \\
M3 I2 & $263,35 \mathrm{tn}$ \\
M4 I2 & $71,45 \mathrm{tn}$ \\
M5 I2 & $55,10 \mathrm{tn}$ \\
\hline Note $:$ tn $:$ not real
\end{tabular}

This was supported by Prewtasari et al (2012) study in his research explaining the use of husk charcoal to get the best results in pakchoi growth by hydroponic planting method, because the use of husk charcoal has an easy property to absorb water and remove excess water, so that the plant does not excess water later it can make stem rot or root rot. This occurs in sawdust media which has the opposite properties of husk charcoal so that in research and during observation it is always found stem rot every time.

\section{Production Weight}

The average production weight of mustard plants is shown in the following table:

Table 16. Average Data of Watering Time Interval (I) on Production Weight of Harvest (G) Mustard Crops Age 5 MST.

\begin{tabular}{ll}
\hline Treatment & Production Weight \\
\hline I1 & $270,54 \mathrm{tn}$ \\
$\mathrm{I} 2$ & $225,59 \mathrm{tn}$ \\
\hline Note $:$ tn : not real &
\end{tabular}

Note : tn : not real

Table 17. Media Average Data (M) in Total Harvest Production (G) Palm Oil Plants at Age 5 MST.

\begin{tabular}{ll}
\hline Treatment & Production Weight \\
\hline M1 & $178,83 \mathrm{bB}$ \\
M2 & $341,25 \mathrm{bA}$ \\
M3 & $648,75 \mathrm{aA}$ \\
M4 & $32,00 \mathrm{cB}$ \\
M5 & $39,50 \mathrm{cB}$ \\
\hline
\end{tabular}

Description: Numbers followed by the same letters in the same column are not significantly different at the level of $\alpha=0.05$ (lowercase letters) and at the level of $\alpha=0.01$ (uppercase) based on Duncan's distance test. 
Table 18. Data on the average interaction of watering time intervals on various media ( $\mathrm{M} \times \mathrm{I})$ on total crop production (g) mustard plants aged 5 MST

\begin{tabular}{ll}
\hline Perlakuan & Bobot Produksi \\
\hline M1 I1 & $207,00 \mathrm{tn}$ \\
M2 I1 & $305,00 \mathrm{tn}$ \\
M3 I1 & $742,50 \mathrm{tn}$ \\
M4 I1 & $42,30 \mathrm{tn}$ \\
M5 I1 & $55,90 \mathrm{tn}$ \\
M1 I2 & $150,65 \mathrm{tn}$ \\
M2 I2 & $377,50 \mathrm{tn}$ \\
M3 I2 & $555,00 \mathrm{tn}$ \\
M4 I2 & $21,70 \mathrm{tn}$ \\
M5 I2 & $23,10 \mathrm{tn}$ \\
\hline Note $\cdot$ tn $:$ not real &
\end{tabular}

Table 16 shows that the watering time interval treatment has no significant effect, in Table 17 shows that the media treatment has a very significant effect on hydroponic media, where M3, M2, M1 have very significant effects on other media while M5 and M4 media have no significant effect. The best media average can be seen in the following graph:

\section{Production Weights}

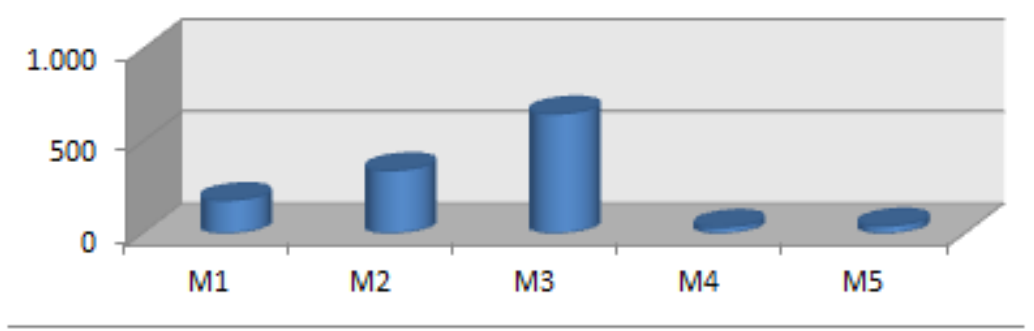

Figure 7. Average Production Weight Graph

The interaction of watering time intervals in various media has no significant effect, but the best production weight on the interaction treatment of watering time intervals on various hydroponic media is shown by the treatment of M3 I1 and M3 I2, namely with an average production weight reaching $742.50 \mathrm{dn} 555.00 \mathrm{~g}$, and production weights the lowest is found in treatment M4 I2, the average production weight is only $21.70 \mathrm{~g}$. Can be broken in Table 18.

This is because a variety of planting media used in planting different types of media including husk charcoal in the M3 media, because husk charcoal has mild characteristics (specific gravity $0.2 \mathrm{~kg} / 1$ ), rough so high air circulation, high water holding capacity, black so that it can absorb sunlight effectively. The sockets are large so that it will be good for aeration and drainage, while the roots will easily move between the chaff charcoal grains (Wuryaningsih, 2010). 
Media M4 from the results of overall observations based on production weights do not show maximum results because M4 media is sawdust which has the opposite properties of husk charcoal so that in research and during observation it is always found stem rot every treatment (Prewtasari et al, 2012).

\section{Conclusion}

1. The treatment of watering liquid fertilizer with different time intervals did not show a significant effect on the growth of mustard plants.

2. The treatment of media used in hydroponic systems has a very significant influence on the parameters of plant height, leaf number, leaf area, production weight and has a significant effect on leaf level parameters, the influential planting media and has the best number is M3 (fuel husk).

3. The interaction of watering time intervals and various types of hydroponic media did not have a significant effect on the parameters observed, including plant height, leaf number, wet weight, and production weight, while the leaf color parameters had significant effect only in the second week and the leaf width parameters were very real on every week of observation.

\section{References}

Anonim. 2005. Sawi. http:// www. iptek. net. id/ind/teknologi_pangan/index. Accessed date 01 December 2010 at 20.45 WIB.

CropKing Inc. 2003. S/CEA vs. Traditional Agriculture. Diakses dari www. cropking. com/sceavs.shtml, 9 May 2004.

Dacoteau, Dennis R. 2000. Vegetable Crops, Prentice Hall Upper Sadle River. New Jersey.

Deptan, 2010. Hortikultura di Indonesia. Departemen Pertanian, Jakarta.

Emigarden, 2008. Media Sekam Bakar. http:॥ media.sekam.com. Retrieved on March 23, 2013.

Harjoko, D. 2003. Mengenal Hidroponik. Makalah dalam Pelatihan Hidroponik Himagron FP UNS, 31 May 2003.

Haryanto, 2003. Sawi dan Selada. Jakarta : Penebar Swadaya

Heru, P dan Yovita, H., I. 2003. Hidroponik Sayuran Semusim Untuk Hobi dan Bisnis. Gramedia, Jakarta.

Karsono, B. dkk. Berkebun Hidroponik Secara Murah. Penebar Swadaya. Jakarta.

Lingga, P. 2002. Hidroponik: Bercocok tanam tanpa tanah. Penebar Swadaya. Jakarta.

Mandha, 2010. Sawi. http://uncategorized-mandha.thm. Retrieved on December 8, 2010.

Margiyanto E., 2010. Cahaya Tani http://Budidaya Tanaman Sawi << Cahaya Tani. Htm. Retrieved on December 8, 2010.

Margiyanto, E. 2007. Hortikultura. Bantul : Cahaya Tani

Muliawati, E.S. 2003. Nutrisi Tanaman dalam Sistem Hidroponik. Makalah dalam Pelatihan Hidroponik Himagron FP UNS, 31 May 2003.

Nazarudin. 2003. Komoditi Ekspor Pertanian Tanaman Pangan dan Hortikultura. Penebar Swadaya. Jakarta.

Prewtasari dkk, 2012. Pengaruh Media Tanam Dan Nutrisi Terhadap Pertumbuhan Dan Hasil Tanaman Pakchoi (Brassica juncea L.) Dengan sistem Hidroponik. Agroteknologi Fakultas Pertanian UTM. 
Prihmantoro, H dan Y.H. Indriani. 2010. Hidroponik Sayuran Semusim untuk Bisnis dan Hobi. Penebar Swadaya. Jakarta.

Rukmana, 2002. Bertanam Petsai dan Sawi. Kanisius, Yogyakarta.

Sastrosupadi, A (2000).Perancangan percobaan praktis Bidang Pertanian. Kanisius, Jakarta

Selvina. F dan Syafrinal. 2008. Pengunaan Berbagai Media Tanam dan Konsentrasi Pupuk Organik Cair Pada Pertumbuhan Dan Produksi Mentimun Jepang (Cucumis sativum) Secara Hidroponik. Fakultas Pertanian Universitas Riau.

Soeseno, A. Hidroponik Bercocok Tanam Tanpa Media Tanah. M2S Bandung. Bandung.

Suhardiyanto, H. 2002. Pengenalan Hidroponik Substrat. Modul Kuliah pada Pelatihan Aplikasi Teknologi Hidroponik untuk Pengembangan Agribisnis Perkotaan. Bogor, 28 Mei - 7 Juni 2002. Pusat Lembaga Penelitian IPB. Bogor.

Sunarjono, H. 2004. Bertanam 30 Jenis Sayur. Penebar Swadaya. Jakarta.

Susanto, S. 2002. Budidaya Tanaman Hidroponik

Modul Kuliah pada Pelatihan Aplikasi Teknologi Hidroponik untuk Pengembangan Agribisnis Perkotaan. Bogor, 28 May - 7 June 2002. Pusat Lembaga Penelitian IPB. Bogor.

Sutiyoso, Y. 2003. Meramu Pupuk Hidroponik. Penebar Swadaya. Jakarta.

Topan. Y. 2009. Pengaruh Berbagai Macam Media Tanam Organik Pada Budidaya Tanaman Caisin (Barassica compestris, var. Chinensis) secara Hidroponik Metode Gerike Modifikasi. Fakultas Pertanian Universitas Andalas. Padang.

Warsito, 2000. Tanaman Hortikultura. Penebar Swadaya. Jakarta.

Widadi. 2003. Food Nutrition. Erlangga. Jakarta.

Wuryaningsih. 2010. Media Tanam. http://stories.media.com. Accessed on 23 March 2013.

Yudharta, 2010. Tanaman Sawi http://tanaman Sawi commudity Aji Chrw-95.htm. Accessed on 12 December 2010 